\title{
Factors associated with the frequency of polypathology among elderly persons receiving care at a referral center in Montes Claros, Minas Gerais
}

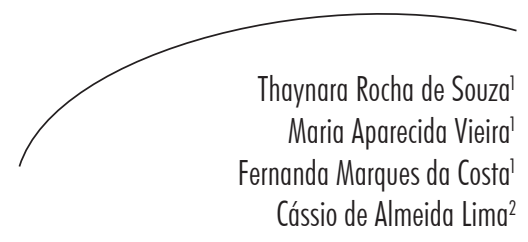

Abstract

Objective: To investigate polypathology among elderly persons treated at a referral center in the state of Minas Gerais, Brazil. Methodology: An analytical documentary study with a cross-sectional quantitative approach was performed. The records of referral and care of 668 elderly persons who were treated at the referral center were analyzed. Bivariate and multivariate analysis was performed using logistic regression. Results: 278 medical records were analyzed. Polypathology was the main reason for seeking care in 114 (41.0\%) cases. There was a statistically significant association between the characteristics of being male and less educated and polypathology. In multivariate analysis, polypathology was higher among men and lower among elderly persons with a high school or higher education. Conclusion: The findings identify a situation with a predominance of polypathology among the elderly. This is at a worrying level among elderly men and less educated older persons, and should be addressed carefully by health professionals, in the search for more specific and appropriate care.

\section{INTRODUCTION}

The diseases that arise due to aging are affected not only by the vulnerability that arises from advanced age, but also by associated risk factors. Such diseases therefore have various causes, which in turn result in polypathologies of the various systems and functions of the body. Polypathology is defined as the state where a person suffers from more than five morbidities, or non-transmissible chronic diseases (NTCDs), such as systemic arterial hypertension (SAH), diabetes mellitus (DM), cerebrovascular accidents (CVA), and osteoporosis, among other diseases. ${ }^{1-3}$

\footnotetext{
Universidade Estadual de Montes Claros, Centro de Ciências Biológicas e da Saúde, Departamento de Enfermagem. Montes Claros, MG, Brasil.

2 Universidade Federal dos Vales do Jequitinhonha e Mucuri, Faculdade de Ciências Biológicas e da Saúde, Programa de Pós-Graduação em Saúde, Sociedade e Ambiente. Diamantina, MG, Brasil.

Key words: Elderly; Health of the Elderly; Aging; Health Services for the Aged. 
The chronicity that characterizes the majority of these diseases causes organic and functional limitations among the elderly that impede them from engaging in activities which were once routine, forcing them to seek help from others or from devices that provide them more safety. The elderly are at risk of being affected by some form of pathology, be it physical, mental or social, placing them in a state of vulnerability or worse, in which they suffer from polypathologies. ${ }^{2,3}$

A significant portion of people that are 60 or older suffer from various diseases that are comorbid, and, in the majority, NTCDs, which may be associated or not with performance limitations that arise from these diseases or from their sequelae. However, even those that suffer from at least one NTCD can live normally if their conditions are kept under control. The maintenance of autonomy is essential for a healthy old age. This can be summed up by the capacity of the elderly person to determine and execute his or her own daily activities. If NTCDs go unmonitored, certain sequelae or forms of incapacitation can arise., ${ }^{4,5}$

Understanding the diseases and the level of impairment they impart on the performance of the daily activities of elderly individuals and, at the same time, identifying what kinds of assistance the elderly person needs is the best path for treating each patient. ${ }^{4}$ Health care professionals should strive to promote activities that postpone limitations to the lifestyle of the elderly. The implementation of the National Policy for the Health of the Elderly Individual is also necessary to encourage the prioritization of healthy living, to prevent aggravating factors from arising and, furthermore, to offer systematic and adequate care with the aim of maintaining the functional capacity of the elderly. ${ }^{6}$

The identification of the characteristics and the factors that are associated with polypathologies among Brazilian elderly persons may help in the planning of activities to promote the rational use of medications and other raw materials in health care centers. Furthermore, such aspects may become factors that can predict the emergence of polypathologies and other health-disease related conditions among the elderly. ${ }^{1,3-5,7,8}$ This knowledge will allow health care services to effectively plan activities and implement new strategies for increasing the amount of attention that is given to the elderly population, especially with respect to polypathologies. In addition, this could be beneficial to the promotion of initiatives that aim to improve the quality of life of this demographic group, especially considering knowledge gaps still exist regarding the phenomenon of polypathology within this population., ${ }^{7,8}$

In this context, the present study aimed to investigate polypathology among elderly patients that are treated at a referral center located in the state of Minas Gerais, Brazil.

\section{METHODOLOGY}

This paper describes an analytical documentary study featuring a cross-sectional quantitative approach. The study was undertaken at the Centro de Referência em Assistência à Saúde do Idoso Eny Faria de Oliveira (Eny Faria de Oliveira Referral Center for Elderly Health Care) (CRASI-EFO), which is located in the city of Montes Claros, in the state of Minas Gerais.

This Center is a branch of the Elderly Health Care Network that cares for high-risk, or vulnerable, elderly patients. In its regulations, the State Health Secretariat of Minas Gerais defines as vulnerable any elderly person exposed to risk factors that can be detected during an evaluation of his or her profile, such as elderly persons that are at least 80 years old and/or elderly persons that are at least 60 years old that suffer from: polypathologies (beginning at five diagnoses), polypharmacy (those who ingest at least five different drugs per day), partial or total immobility, postural instability or repeated falls, urinary or bowel incontinence, cognitive incapacitation (upon presenting cognitive decline, dementia syndrome, depression or delirium), a history of frequent hospitalization and/or postdischarge hospitalization, being dependent on others to conduct their basic activities of daily living (Basic ADLs), familial insufficiency, and specifically elderly persons that are socially vulnerable, not only in their family lives, but also as residents of extended care facilities for the elderly. 
These elderly patients are referred by teams from the Atenção Primária à Saúde (Primary Health Monitoring Service) (APS), or some other such service, through an appointment that is made by the Central de Regulação Assistencial (Care Regulation Center) under the supervision of the Municipal Health Secretariat of Montes Claros.

Because the research study followed the analytical documentary format, it made use of the following documents: Referral Forms and Patient Care Forms from 668 elderly persons residing in Montes Claros, Minas Gerais, who received primary care at the CRASI-EFO during the period of June to August, 2012. The 668 medical records were distributed among the elderly patients as follows: July (295 consultations) and August (373 consultations). Among these, researchers found that 278 medical records $(42.0 \%)$ contained information regarding the motive of the consultation at CRASI$\mathrm{EFO}$, while the rest of the records did not contain information regarding polypathologies.

The dependent variable - polypathology - was constructed based on the categorization of the quantity of diseases that were described in the medical treatment records of the elderly patients. According to the Ministry of Health, a diagnosis of five or more simultaneous diseases is sufficient to prescribe a diagnosis of polypathology, in addition to the fact that the treatment of one disease may interfere with the treatment of another. As such, researchers considered the elderly persons that were diagnosed with five or more diseases as a positive result for polypathology, while a negative result for polypathology was considered to be those elderly persons that were diagnosed with less than five diseases. ${ }^{10}$

As a result, only those medical records that stated the motive for a medical consultation at CRASI-EFO were included, which made it possible to identify the presence, or lack thereof, of polypathologies.

To guide the collection of data, a data collection spreadsheet was used which was adapted from the Elderly Patient Care Forms and the Elderly Referral Forms. Based on these documents, the following variables were obtained: the APS that referred the elderly person to the CRASI; the motive for the referral; age; gender; marital status; academic background; color/race according to the elderly person or caregiver; whether the elderly person had a retirement fund; who accompanied the elderly person during the medical consultation; the health care professionals that provided treatment at the CRASI-EFO; which medications the elderly person takes and information regarding pathology. These variables were selected because they are contained in the data collection documents, in addition to being present in the literature about this subject matter. ${ }^{1,3-5,7,8,11-13}$

The Elderly Patient Care Form information was collected from the digital database software of CRASI-EFO, while the Elderly Referral Form information, which was found on hard copies, was obtained from the file repository of the institution.

The data was analyzed in the Predictive Analytics Software $\left(P A S W^{\circledR}\right)$, version 18.0, for Windows. The data was submitted to descriptive analyzes that verified for relative and absolute frequencies, measurements of central tendency and dispersion, and the association of discrete variables using the Pearson Chi-squared test. The Student's t-test was used for the numerical variables in order to compare mean values. The association between polypathology and the independent variables was studied through a bivariate multiple analysis that included Logistic Regression. Initially, the variables that were associated with polypathology in the bivariate analysis were included in the multiple analysis at a $p$ value of $<0.20$. Afterwards, each of the variables was included one by one to adjust the final model. A $5 \%(p \leq 0.05)$ significance level was stipulated for the final model.

The study was conducted in accordance with the ethical standards regarding research studies with human participants, in accordance with the guidelines of Resolution No. 466/2012 of the National Health Council. The necessary debriefing regarding the execution of the study and regarding ethical principles was provided to the Coordenação de Apoio à Pesquisa do Hospital Universitário Clemente Faria (the Department of Support for Research of the Clemente Faria University Hospital), which administers CRASI- 
EFO. Department officials were then asked to read and sign the Term of Institutional Agreement to Participate in a Research Study. The research project was approved by the Research Ethics Committee of the Universidade Estadual de Montes Claros, as per consolidated normative statement No. 275.228/2013 and Presentation Certificate for Ethical Authorization: 15859813.3.0000.5146.

\section{RESULTS}

Six hundred and sixty-eight medical records were examined, of which $278(42.0 \%)$ contained information regarding the motive for the consultation. In the remaining medical records, no such information was encountered, thereby eliminating these records from the study.
Among 114 (41.0\%) of the 278 medical records, polypathology was the main reason believed to explain why medical treatment was sought at the CRASI-EFO. The characterization of the 278 elderly persons was distributed according to sociodemographic aspects and the characteristics of the treatment given (table 1).

The characteristics associated with polypathology in the bivariate analysis $(p<0.20)$ were gender and academic background (table 2).

Multiple analysis revealed that the variables of gender and academic background were associated $(p \leq 0.05)$. It was noted that polypathology was more frequent among men. On the other hand, polypathology was less frequent among elderly persons who had graduated from high school or had a higher or further education (table 3).

Table 1. Characterization of elderly persons treated $(\mathrm{N}=278)$ at the CRASI-EFO. Montes Claros, Minas Gerais, 2012.

\begin{tabular}{|c|c|c|}
\hline Variables & $\mathrm{n}$ & $\%$ \\
\hline \multicolumn{3}{|l|}{ Sociodemographic } \\
\hline \multicolumn{3}{|l|}{ Gender } \\
\hline Female & 195 & 70.1 \\
\hline Male & 83 & 29.9 \\
\hline \multicolumn{3}{|l|}{ Marital Status } \\
\hline Single & 34 & 12.2 \\
\hline Married & 112 & 40.3 \\
\hline Widow/Widower & 132 & 47.5 \\
\hline \multicolumn{3}{|l|}{ Academic Background } \\
\hline Illiterate & 125 & 45.0 \\
\hline Elementary schooling & 133 & 47.8 \\
\hline High school and further & 20 & 7.2 \\
\hline \multicolumn{3}{|l|}{ Age } \\
\hline Between 60 and 70 & 92 & 33.1 \\
\hline Between 71 and 79 & 100 & 36.0 \\
\hline Over 80 years old & 86 & 30.9 \\
\hline \multicolumn{3}{|l|}{ Color/race (self-declared) } \\
\hline Dark-skinned & 220 & 79.1 \\
\hline Other & 58 & 20.9 \\
\hline \multicolumn{3}{|l|}{ Treatment characteristics } \\
\hline \multicolumn{3}{|l|}{ Presence of a caregiver during consultation } \\
\hline Family members & 142 & 51.1 \\
\hline Other (caretakers/neighbors) & 136 & $\begin{array}{r}48.9 \\
\text { uns on }\end{array}$ \\
\hline
\end{tabular}




\begin{tabular}{lcc}
\hline \multicolumn{1}{c}{ Variables } & $\mathbf{n}$ & \% \\
\hline Unit that referred the patient & & \\
Family Health Strategy & 155 & 55.8 \\
Health Care Center & 123 & 44.2 \\
Staff that provided treatment & & \\
Doctor or nurse & 146 & 52.5 \\
Multi-professional team & 132 & 47.5 \\
\hline
\end{tabular}

Table 2. Results of the bivariate analysis of polypathology and sociodemographic variables and the characteristics of the treatment that the elderly received $(\mathrm{N}=278))$ at the CRASI-EFO. Montes Claros, Minas Gerais, 2012.

\begin{tabular}{|c|c|c|c|c|c|}
\hline \multirow[b]{3}{*}{ Variables } & \multicolumn{4}{|c|}{ Polypathology } & \multirow{3}{*}{$\mathrm{p}$-value } \\
\hline & \multicolumn{2}{|c|}{ Yes } & \multicolumn{2}{|c|}{ No } & \\
\hline & $\mathbf{N}$ & $\%$ & $\mathrm{n}$ & $\%$ & \\
\hline \multicolumn{6}{|l|}{ Sociodemographic } \\
\hline \multicolumn{6}{|l|}{ Gender } \\
\hline Female & 72 & 36.9 & 123 & 63.1 & \\
\hline Male & 42 & 50.6 & 41 & 49.4 & 0.02 \\
\hline \multicolumn{6}{|l|}{ Marital Status } \\
\hline Single & 15 & 44.1 & 19 & 55.9 & \\
\hline Married & 44 & 39.3 & 68 & 60.7 & \\
\hline Widow/Widower & 55 & 41.7 & 77 & 58.3 & 0.86 \\
\hline \multicolumn{6}{|l|}{ Academic Background } \\
\hline Illiterate & 51 & 40.8 & 74 & 59.2 & \\
\hline Elementary schooling & 60 & 45.1 & 73 & 54.9 & 0.03 \\
\hline High school and further & 3 & 15.0 & 17 & 85.0 & 0.02 \\
\hline \multicolumn{6}{|l|}{ Age } \\
\hline Between 60 and 70 & 42 & 45.7 & 50 & 54.3 & \\
\hline Between 71 and 79 & 36 & 36.0 & 64 & 64.0 & 0.39 \\
\hline Over 80 years old & 36 & 41.9 & 50 & 58.1 & 0.38 \\
\hline \multicolumn{6}{|l|}{ Color/race (self-declared) } \\
\hline Dark-skinned & 21 & 36.2 & 37 & 63.8 & \\
\hline Other & 93 & 42.3 & 127 & 57.7 & 0.24 \\
\hline \multicolumn{6}{|l|}{ Treatment characteristics } \\
\hline \multicolumn{6}{|c|}{ Presence of a caregiver during consultation } \\
\hline Family members & 62 & 43.7 & 80 & 56.3 & \\
\hline Other (caretakers/neighbors) & 52 & 38.2 & 84 & 61.8 & 0.21 \\
\hline \multicolumn{6}{|l|}{ Unit that referred the patient } \\
\hline Family Health Strategy & 61 & 36.4 & 94 & 60.6 & \\
\hline Health Care Center & 53 & 43.1 & 70 & 56.9 & 0.30 \\
\hline
\end{tabular}




\begin{tabular}{lcccccc}
\hline & \multicolumn{7}{c}{ Polypathology } \\
\multicolumn{1}{c}{ Variables } & Yes & & & No & p-value \\
& N & & $\%$ & n & $\%$ & \\
\hline Staff that provided treatment & & & & & & \\
$\quad$ Doctor or Nurse & 62 & 42.5 & 84 & 57.5 & \\
Multi-professional Team & 52 & 39.4 & 80 & 60.6 & 0.34 \\
\hline
\end{tabular}

Table 3. Final model of the factors associated with polypathology among the elderly persons treated $(\mathrm{N}=278)$ at the CRASI-EFO. Montes Claros, Minas Gerais, 2012.

\begin{tabular}{lccc}
\hline \multicolumn{1}{c}{ Independent variables } & OR adjusted & CI 95\% & p-value \\
\hline Gender & 1 & & \\
$\quad$ Female & 1.68 & $1.09-2.85$ & 0.05 \\
$\quad$ Male & 1 & & \\
Academic Background & 1.16 & $0.70-1.91$ & 0.55 \\
$\quad$ Illiterate & 0.26 & $0.07-0.95$ & 0.04 \\
$\quad$ Elementary schooling & & & \\
High school and further & & & \\
\hline
\end{tabular}

\section{DISCUSSION}

The findings of the present study were similar to those encountered in a domiciliary study that was undertaken in the urban area of the municipality of Uberaba, in the state of Minas Gerais, whose aim was to compare the number of morbidities among the elderly with the variables of gender, academic background, individual income, their use of health care services and their number of functional incapacitations. This analysis found that the largest number of morbidities was proportionally larger among women; among elderly persons with less education; among those with a lower individual income; among those that seek out health care services more often; among those that were hospitalized more frequently and among those that had more functional incapacitations. ${ }^{11}$

The present study, however, found that polypathology predominated among men. Such a finding may be the result of factors that are related to behavior, to the use of health care services or to gender relations among the men that were studied. Because of these factors, men seek out health care services less frequently, adopt unhealthy behaviors, and, as a result, display a greater propensity to develop polypathologies when they become elderly. ${ }^{1,8,12}$

Similarly, a cross-sectional study that identified the profile of morbidity and the use of health care services among elderly persons treated by the Family Health Strategy (FHS) of Antônio Estevão de Carvalho in the state of São Paulo, found that health problems were described by $93.5 \%$ of the elderly, of whom $52.3 \%$ described suffering from two to five NTCDs. However, in contrast with that study, a greater number of elderly women were found to have from two to five pathologies, whereas men predominantly suffered from just one. ${ }^{12}$

A salient characteristic in terms of elderly health care is related to the use of the services that are offered by the APS and FHS. In the present study, the majority of the elderly were referred by the FHS. It should be noted that, according to a study that investigated the tendencies of the health status of Brazilian elderly persons over a period of ten 
years, which was characterized by the Pesquisa Nacional por Amostra de Domicílios (National Study of Household Sampling), results showed positive tendencies in the health conditions of the Brazilian elderly population with respect to various, but not all, domains. The changes in the use of health services occurred as expected due to the expansion of the activities of the APS in Brazil. ${ }^{13}$

These changes may explain the results that were observed during this study, since similar parameters were found in Montes Claros: the municipality has achieved a positive restructuring of the service network of the FHS in addition to overall improvements in the coverage of the population. Expansion regarding such services has also been noted in municipalities in the northern region of the state of Minas Gerais, which certainly provides the elderly population with better access to the health care network of the area. The CRASI-EFO is a key institution in this network. In addition, Montes Claros is considered to be a model city in terms of its regional network of health care facilities. In this sense, the impact that quality health care for the elderly has on morbidity and mortality indicators among this demographic can clearly be observed.

Polypathologies can make the elderly person more vulnerable to factors that contribute to a dependency on others to perform basic daily living activities. ${ }^{14}$ In this sense, the polypathology phenomenon, which is one of the issues that arises from aging populations, is, today, a reality that health care professionals should be aware of. As such, health care staff must be qualified to deal with this particular aspect of the daily lives of elderly people. ${ }^{11}$ Polypathology is therefore a complicated issue within the field of geriatrics. Therefore, continual education and training of health care professionals to deal with polypathologies is required, allowing them to provide higher quality care.

In the present study, the parameter of gender was significantly associated with polypathology, a finding which differed from the results of a study conducted in the city of Fortaleza, in the state of Ceará, where polypathologies were prevalent among women. ${ }^{15}$ Among the polypathologies found, cardiovascular diseases were the most prevalent and have been found to be responsible for a third of all deaths among women worldwide, and half of all deaths among women over the age of 50 in developing countries, just as in the United States and Canada. This fact may be associated with greater tendencies in terms of sedentariness and obesity, the loss of sex hormone protection due to menopause, and the sociodemographic and clinical conditions found among elderly women. ${ }^{15,16}$

On the other hand, the results of the present study regarding gender reflect the fact that women live longer on average than men. The fact that women attend health care clinics more often than men should also be considered, as they seek out the services of the FHS with greater frequency. The tendency for women to live longer, as they have a lower rate of mortality than men, occurs all over the world, but this does not mean that women are necessarily exposed to better health care conditions. ${ }^{12,17,18}$ As a result, it should be considered that, while women are exposed to factors that preserve their health, and, in this study, presented lower frequencies of polypathology, this does not remove the responsibility of medical professionals to care for elderly women. This scenario strengthens the fact that quality, permanent care is required for this segment of the population.

The multiple analysis performed during the present study revealed that the incidence of polypathology was lower among elderly persons who had graduated from high school or college. This result corroborates with the findings of a study that showed that fewer years of education resulted in cognitive deficiencies. ${ }^{14}$ In a study that was undertaken in the municipality of Uberaba, in the state of Minas Gerais, where the incidence of morbidities was compared to years of education, a greater proportion of elderly persons with less education suffered from more than three morbidities, whereas those that had more than eight years of study did not suffer from any morbidities. Various factors may be related to these findings, one of the most notable being greater access to, and a better comprehension of, health-related information. ${ }^{11}$

The parameter academic background is highly influential on the health status of a population. 
Elderly persons who have more education enjoy greater autonomy and are more apt to care for themselves and to use various modes of transportation and communication. On the other hand, elderly persons with less education are more susceptible to diseases and, as such, impose greater demands on the health care community, an important fact which must be recognized. The influence of socioeconomic factors must also be noted in this context since, during the infant years of many of these elderly individuals, schooling was a privilege available to few. Within the conditions in which the majority were raised, younger boys had to cultivate the land, while girls had to help their mothers with household chores ${ }^{15}$ which was a common lifestyle in the north of Minas Gerais during the youth of many elderly people.

Elderly individuals with less education may have difficulty in accessing health care services and may not be as aware of the risks that polypathology can pose. ${ }^{1}$ This parameter is relevant, because it strengthens the importance of providing people with orientation, especially elderly individuals that are facing a stage of their lives where they require much more attention and care. This is especially true when challenges arise from insufficient schooling, as these limitations can exacerbate health issues among the elderly. ${ }^{19}$

The association between years of education, better quality of life and being able to care for oneself has been discussed in literature concerning this subject matter. ${ }^{1,3,4,6-8,11,13,14,17,18}$ From this perspective, both regarding the care context of the present study and that of other health care services, the association mentioned above must be considered. Whenever health care education activities are undertaken, health care professionals should address the elderly patient with language and terminology that they can readily comprehend. Similarly, visual communication must be emphasized during the production of posters with the aim of reaching the target audience. Unfortunately, the process of human aging may bring about reductions in hearing and sight, which can interfere with communication. It is therefore necessary to improve interpersonal relationships and maintain regular dialogue with elderly individuals. ${ }^{11}$

With elderly populations on the rise and increases in the average age of the elderly, the impact of this segment of the population on specialized health care services will also increase in addition to how much is spent on them, making this scenario one of the greatest economic challenges Brazil will face in the coming decades. From this point the necessity of an inversion of the current logic of the country's health care system, currently focused on the treatment of diseases that already exist, rather than on activities that encourage healthy living and disease prevention, emerges. The current status of the system engenders poor quality of life, ${ }^{20,21}$ as evidenced by the polypathologies found in this study.

The present study was limited by its crosssectional design, making cause and effect statements and statements concerning the documentary evidence impossible due to problems in the proper completion of the medical records. Because of these limitations, further studies concerning this subject matter should be undertaken in order to investigate it more comprehensively.

\section{CONCLUSIONS}

This study investigated a troubling reality: in the majority of cases in which treatment was sought at the referral center for elderly health care in question, polypathology was found to be the prevalent motive. Elderly men and those elderly persons that had less education were shown to be even more vulnerable, since these parameters were shown to be associated with a greater incidence of polypathologies.

These findings define a scenario of concern not only to health care professionals, but also those individuals that care for elderly persons in the Atenção Primária à Saúde (Primary Health Monitoring Service) network, with the aim of developing more specific care that is effective in treating the condition of polypathology. 


\section{REFERENCES}

1. Santos TRA, Lima DM, Nakatani AYK, Pereira LV, Leal GS, Amaral RG. Medicine use by the elderly in Goiania, Midwestern Brazil. Rev Saúde Pública 2013;47(1):94-103.

2. Maciel ACC, Araújo LM. Fatores associados às alterações na velocidade de marcha e força de preensão manual em idosos institucionalizados. Rev Bras Geriatr Gerontol 2010;13(2):179-89.

3. Garrido R, Menezes PR. O Brasil está envelhecendo: boas e más notícias por uma perspectiva epidemiológica. Rev Bras Psiquiatr 2002;24(supl. 1):3-6.

4. Rodrigues RAP, Scudeller PG, Pedrazzi EC, Schiavetto FV, Lange CA. Morbidity and interference in seniors functional ability. Acta Paul Enferm 2008;21(4):643-8.

5. Baldoni AO, Ayres LR, Martinez EZ, Dewullf NLS, Santos V, Obrelineto PR, et al. Pharmacoephidemiological profile and polifarmacy indicators in eldery outpatients. J Pharm Sci 2013;49(3):443-52.

6. Brasil. Portaria no 2.528, de 19 de Outubro de 2006. Aprova a Política Nacional de Saúde da Pessoa Idosa. Diário oficial da União. Brasília (DF), 2006.

7. Silva AL, Ribeiro AQ, Klein CH, Acurcio FA. Utilização de medicamentos por idosos brasileiros, de acordo com a faixa etária: um inquérito postal. Cad Saúde Pública 2012;28(6):1033-45.

8. Neves SJF, Marques APO, Leal MCC, Diniz AS, Medeiros TS, Arruda IKG, et al. Epidemiology of medication use among the elderly in an urban area of Northeastern Brazil. Rev Saúde Pública 2013;47(4):1-10.

9. Minas Gerais. Secretaria do Estado de Saúde. Normas gerais do Programa Mais Vida - Rede de Atenção à Saúde do Idoso de Minas Gerais. Resolução SES n ${ }^{\circ}$ 1583 de 19 de Setembro de 2008. Belo Horizonte, 2008.

10. Moraes EM. Atenção à saúde do idoso: aspectos conceituais. Brasília: Organização Pan-Americana da Saúde; 2012.

11. Santos SAL, Tavares DMS, Barabosa MH. Fatores socioeconômicos, incapacidade funcional e número de doenças entre idosos. Rev Eletr Enf. [Internet]. 2010 [Acesso em 24 fev 2015];12(4):692-7. Disponível em: http://www.fen.ufg.br/revista/v12/ n4/v12n4a14.htm.
12. Cabrelli R, Sousa CS, Turrini RNT, Cianciarullo TI. Idosos na unidade de saúde da família: morbidade e utilização de serviços de saúde. Rev Rene 2014;15(1):89-98.

13. Lima-Costa MF, Matos DL, Camargos VP, Macinko J. Tendências em dez anos das condições de saúde de idosos brasileiros: evidências da Pesquisa Nacional por Amostra de Domicílios (1998, 2003, 2008). Ciênc Saúde Coletiva 2011;16(9):3689-96.

14. Ferreira PCS, Tavares DMS, Rodrigues RAP. Características sociodemográficas, capacidade funcional e morbidades entre idosos com e sem declínio cognitivo. Acta Paul Enferm 2011;24(1):29-35.

15. Clares JWB, Freitas MC, Almeida PC, Galiza FT, Queiroz TA. Perfil de idosos cadastrados numa unidade básica de saúde da família de Fortaleza-CE. Rev Rene 2011;12(n. esp.):988-94.

16. Pilote L, Dasgupta K, Guru V, Humphries KH, McGrath J, Norris C, et al. A comprehensive view of sex-specific issues related to cardiovascular disease. CMAJ 2007;176(6):S1-44.

17. Farias RG, Santos SMA. Influência dos determinantes do envelhecimento ativo entre idosos mais idosos. Texto Contexto Enferm 2012;21(1):167-76.

18. Pereira RJ, Cotta RMM, Franceschini SCC, Ribeiro RCL, Sampaio RF, Priore SE, et al. Influência de fatores sociossanitários na qualidade de vida dos idosos de um município do Sudeste do Brasil. Ciênc Saúde Coletiva 2011;16(6):2907-17.

19. Silva CSO, Pereira MI, Yoshitome AY, Rodrigues Neto JF, Barbosa DA. Avaliação do uso de medicamentos pela população idosa em Montes Claros, Minas Gerais, Brasil. Esc Anna Nery 2010;14(4):811-8.

20. Veras RP. Prevenção de doenças em idosos: os equívocos dos atuais modelos. Cad Saúde Pública 2012;28(10):1834-40.

21. Lim SS, Vos T, Flaxman AD, Danaei G, Shibuya K, Adair-Rohani $\mathrm{H}$, et al. Comparative risk assessment of burden of disease and injury attributable to 67 risk factors and risk factor clusters in 21 regions, 19902010: a systematic analysis for the Global Burden of Disease Study 2010. Lancet 2012;380:2224-60. 